\title{
ANALISIS KEHILANGAN STEAM DAN PENURUNAN TEMPERATUR PADA JARINGAN DISTRIBUSI STEAM DARI PT. KDM KE PT. KNI
}

\author{
Ahmad Yani ${ }^{1}$, Ristyohadi $^{2}$ \\ Jurusan Teknik Mesin Universitas Trunajaya Bontang. ${ }^{1,2}$ \\ Jl.Taekwondo RT.9 No. 55 Telp./Fax. (0548) 3035920 Bontang-Kaltim 75311 \\ Email: yanibima@gmail.com¹, ristyohadi@gmail.com²
}

\begin{abstract}
ABSTRAK
Steam adalah sumber energi yang banyak dipakai dalan dunia industri modern saat ini Petro Chemical, Oil and Gas, Healt and Food, fertilliser demikian juga dengan PT. Kaltim Nitrate Indonesia, sebagai penghasil Ammonium Nitrate kelas dunia, tentu memerlukan steam dalam jumlah yang sangat besar. Untuk memenuhi kebutuhan akan steam diperlukan adanya jaringan pipa distribusi atau pipe line steam dari PT. Kaltim Daya Mandiri hingga metering station yang ada di PT. Kaltim Nitrate Indonesia. Berdasarkan data awal pada Direct Control System, ada kehilangan steam (steam loss) sebesar 2.5 ton per jam dan penurunan temperatur yang sangat signifikan yaitu sebesar $96{ }^{\circ} \mathrm{C}$. Line steam ini menggunakan pipa Crommoly berdiameter 8" (200 mm) sepanjang 1008 Meter, terhubung dengan header dengan tekanan tinggi Sehingga tekanan steam sepanjang jalur distribusi relatif stabil. Untuk mengurangi perpindahan panas yang terjadi, di sepanjang jalur distribusi di pasang lapisan pelindung panas (Insulation). Namun demikian karena sifat steam yang mudah kehilangan panas karena konduksi, konveksi dan radiasi maka terjadi perpindahan panas secara simultan yang mengakibatkan steam mengalami kondensasi atau perubahan fase dari uap kering menjadi uap basah atau cairan. Proses pembuangan air dilakukan oleh steam trap namun sering terjadi malah steam ikut terbuang percuma karena adanya kebocoran pada steam trap hal inilah yang menyebabkan adanya kehilangan steam dan penurunan temperatur di sepanjang jalur distribusi steam dari Kaltim Daya Mandiri menuju Kaltim Nitrate Indonesia.

Tujuan penelitian ini dilakaukan untuk mencari penyebab terjadinya kehilangan steam dan penurunan temperature jaringan pipa distribusi atau pipe line steam. Dari hasil penelitian didapatkan penyebab terjadinya kehilangan steam dan penurunan temperature jaringan pipa distribusi atau pipe line steam:

1. Kehilangan steam diakibatkan oleh dua faktor utama yaitu:

a. Laju perpindahan secara simultan yang terjadi pada jalur distribusi.

b. Kondisi steam trap yang bocor (leaking)

2. Penurunan temperatur secara signifikan terjadi karena perubaham fase.

3. Perlu pengecekan dan perbaikan berkala sehingga setiap kerusakan yang terjadi dapat diketahui secara dini.
\end{abstract}

Kata Kunci: kehilangan uap (steam loss), penurunan temperatur, dan jaringan distribusi.

\section{PENDAHULUAN}

Steam merupakan sumber energi yang sangat potensial dan banyak digunakan di berbagai industri dewasa ini, Petro Chemical, Power Plant, Oil and Gas, Fertilliser, Food and Beverage, Manufacturing. Selain bersih steam juga memiliki banyak keunggulan dibandingkan dengan sumber energi lainnya antara lain tidak mencemari lingkungan, mudah di pindahkan dari suatu tempat ketempat yang lainnya, memiliki energi potensial yang tinggi, temperatur yang bervariasi sehingga sangat tepat digunakan transfer panas pada exanger maupun alat penukar panas lainnya. Namun steam juga memiliki kelemahan terutama dari sifatnya yang mudah kehilangan panas karena proses 
konduksi, konveksi, radiasi dan mudah mengalami kondensasi atau berubah fase menjadi air kembali pada tekanan dan temperatur tertentu. Karena sifat steam yang demikianlah maka diperlukan suatu line atau jalur perpipaan yang berbeda dari fluida lainnya. Salah satu persyaratannya adalah adanya pelindung panas yang mampu menahan panas dan mencegah kehilangan panas karena radiasi.[1]

Untuk menghasilkan Ammonium Nitrate kelas dunia PT. Kaltim Nitrate Indonesia sangat bergantung pada pasokan Steam. Terutama untuk menaikan suhu Ammonia cair menjadi Gas pada Ammonia Evaporator. Pada tahap ini steam dialirkan melalui pipa pipa kecil dalam alat penukar panas, tujuanya adalah terjadi pertukaran panas antara Ammonia cair dengan steam sehingga terjadi penguapan. Selain itu steam juga digunakan untuk memutar turbin secara terus menerus. Disinilah kondisi steam benar benar dijaga terutama temperatur, tekanan, kandungan air dan kecepatan alir (velocity) sehingga putaran turbin tetap stabil. Putaran turbine digunakan untuk memutar kompresor Nox dan udara, jadi jika dorongan steam terhadap turbin berkurang maka akan berpengaruh terhadap jumlah Nox dan udara yang dihasilkan, padahal dua unsur inilah yang sangat penting dalam memproduksi Nitric Acid sebelum direaksikan kembali dengan Ammonia panas untuk membuat Ammonium Nitrate. Seperti yang pernah dijelaskan sebelumnya untuk memenuhi kebutuhan steam yang begitu besar mengingat PT. Kaltim Nitrate Indonesia belum memiliki boiler tersendiri, maka diperlukan pasokan steam dari PT. Kaltim Daya Mandiri melalui pipa distribusi steam dengan diameter Pipa 8" sepanjang $1200 \mathrm{~m}$. Untuk mengalirkan steam dalam jumlah besar tersebut bukanlah hal yang mudah, diperlukan perencanaan dan desain kalkulasi yang sangat tepat sehingga steam tetap dapat mengalir dengan sempurna walaupun pada kenyataannya terjadi kehilangan steam dalam jumlah yang sangat besar, 2 ton per jam bukanlah jumlah yang sedikit bagi PT. Kaltim Nitrate Indonesia, dengan berkurangnya steam secara otomatis terjadi penurunan temperatur yang sangat signifikan yaitu $82{ }^{\circ} \mathrm{C}$.[2]

Dari uraian diatas dapat disimpulkan bahwa setelah melewati pipa sepanjang 1008 meter maka terjadi kehilangan steam sebesar 3,5 ton per jam dan penurunan temperatur sebesar $98^{\circ} \mathrm{C}$. hal inilah yang mendorong penulis melakukan penelitan ini. Dengan melakukan penelitian ini diharapkan peneliti mampu menyajikan data dan perhitungan yang akurat penyebab hilangnya steam dan penurunan temperatur yang terjadi pada jalur distribusi steam dari Kaltim daya Mandiri menuju Kaltim Nitrate Indonesia, sehingga mampu memberikan masukan dan solusi yang tepat untuk melakukan perbaikan.

Tujuan dari penelitian ini yaitu:

1. Mengetahui penyebab terjadinya kehilangan steam sepanjang saluran distribusi steam.

2. Mengetahui penyebab terjadinya penurunan temperatur steam sepanjang saluran distribusi steam.

3. Mendapatkan solusi yang tepat untuk perbaikan dan mengurangi kerugian karena kehilangan steam dan penurunan temperatur.

\section{TINJAUAN PUSTAKA}

\section{Perpindahan Panas}

Perpindahan panas adalah ilmu yang mempelajari perpindahan energi pada suatu bahan karena adanya perbedaan (gradien) Suhu. Perpindahan panas ini selalu terjadi dari suatu sistem bersuhu tinggi ke sistem lain yang bersuhu lebih rendah dan berhenti setelah kedua sistem mencapai temperature yang sama, perbedaan temperature merupakan syarat utama terjadinya perpindahan kalor, jika kedua sistem mempunyai temperature yang sama maka tidak akan ada perpindahan kalor pada kedua sistem tersebut. Jumlah aliran panas dinyatakan dengan notasi Q dalam satuan energi yaitu joule (j). 
Sedangkan laju aliran panas adalah aliran energi persatuan waktu (jam atau detik) dinyatakan dengan notasi $Q(Q$ dot) pada umumnya dalam watt (W). Selain itu ada juga laju aliran panas per satuan luas (q dot) yang sering disebut fluks panas atau aliran panas spesifik. Harga Q dan q adalah suatu vektor yang arahnya berimpit dengan arah penyebaran panas. [5]

Ilmu perpindahan kalor tidak hanya mencoba menjelaskan bagaimana energy kalor itu berpindah dari satu benda ke benda lain, tetapi juga dapat meramalkan laju perpindahan panas yang terjadi pada kondidi-kondisi tertentu. Terdapat tiga macam perpindahan panas, yaitu konduksi, konveksi, dan radiasi. [3]

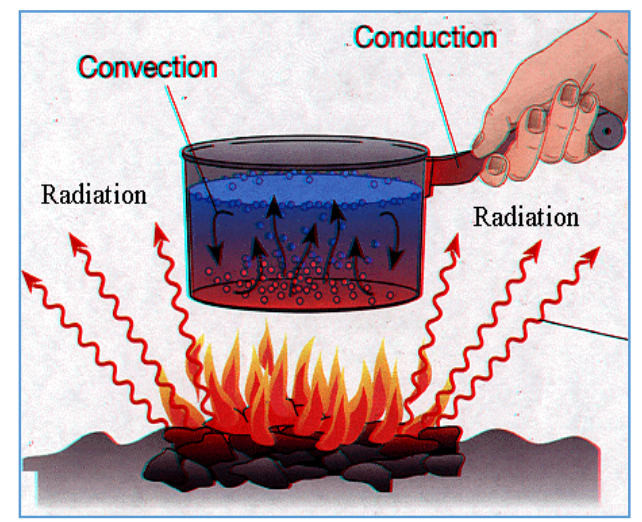

Gambar 1. Proses Perpindahan panas

\section{Perpindahan Panas Konduksi}

Konduksi ialah perpindahan panas pada benda padat dari daerah bertemperatur tinggi ke daerah bertemperatur rendah. Menurut Fourrier, kecepatan aliran sebanding dengan luas permukaan yang dilalui panas dan perbedaan temperatur serta berbanding terbalik dengan tebal dinding yang dilalui. [4]

$q=-K A \frac{d T}{d x}$

Dimana:

$\mathrm{q}=$ Laju perpindahan panas (Watt)

$\mathrm{K}=$ Kondutivitas termal $\left(\mathrm{W} / \mathrm{m}^{\circ} \mathrm{C}\right)$

$\mathrm{A}=$ Luas permukaan yang terletak pada aliran panas $\left(\mathrm{m}^{2}\right)$

$\mathrm{dT}=$ Beda temperatur permukaan $\left(\mathrm{K} /{ }^{\circ} \mathrm{C}\right)$

Dimana $(\mathrm{K})$ adalah konduktivitas termal, tanda negatif (-) menyatakan bahwa makin tebal makin turun temperatur di balik dinding tesebut.

Konduktivitas termal (K) adalah konstanta keseimbangan yang dapat didefinisikan dari hukum Fourier. Konduktivitas termal merupakan sifat fisik bahan dan sifat kemampuan bahan memindahkan panas. Setiap bahan mempunyai konduktivitas termal yang berbeda dan tergantung pada struktur fisik bahan, berat jenis, kelembaban, tekanan dan temperatur.

\section{Perpidahan Panas konveksi}

Perpindahan panas konveksi adalah suatu mekanisme perpindahan panas antara permukaan padat dengan fluida incompressible maupun compressible yang bergerak dan melibatkan konduksi serta gerakan dari fluida tersebut. Semakin cepat gerakan fluida maka, semakin besar laju perpindahan panas konveksinya. Atas dasar suatu proses pendinginan balok panas yang di tiupkan udara dingin maka proses perpindahan panas konveksi akan terjadi melalui beberapa tahap, pertama energi panas akan mengalir secara konduksi dari permukaan benda padat ke partikel-partikel lapisan fluida yang berbatasan, kemudian energy ini akan terbawah menjauh dari permukaan benda padat melalui mekanisme konveksi, yang mana terdapat dua proses yang terjadi secara bersamaan yaitu kombinasi dari efek konduksi di dalam fluida akibat gerakan acak antar partikelpartikel fluida yang terjadi secara mikroskopis sehingga partikel fluida yang memiliki energi lebih tinggi akan memindahkan sebagian energinya pada partikel fluida yang memiliki energy lebih rendah, serta adanya gerakan fluida secara makroskopis yang akan menggantikan fluida yang telah panas di sekitar permukaan benda padat dengan fluida dingin. [5]

Proses perhitungan dengan mengunakan persamaan berikut: [5]

Untuk laju perpindahan panas konduksi yang terjadi sepanjang jalur 
distribusi:

Qkond $=\frac{2 \pi L\left(T_{1}-T_{5}\right)}{\sum_{i=1}^{n} \frac{1}{k_{1}} \ln \frac{d n_{1}}{d_{1}}}$
$\frac{\text { Qkond }}{L}=\frac{2 \pi\left(T_{1}-T_{5}\right)}{\sum_{i=1}^{n} \frac{1}{k_{1}} \ln \frac{d n_{1}}{d_{1}}}$

Untuk mengetahui temperatur permukaan pipa $\left(\mathrm{T}_{2}\right)$ dapat kita cari dengan persamaan:

$T_{2}=T_{1}-\frac{\frac{Q k o n d}{L}}{2 \pi} x \frac{1}{k_{1}} \ln \frac{d_{2}}{d_{1}}$
$T_{3}=T_{2}-\frac{\frac{Q k o n d}{L}}{2 \pi} x \frac{1}{k_{2}} \ln \frac{d_{3}}{d_{2}}$

Setelah semua temperatur permukaan pipa dan isolasi saluran distribusi steam diketahui selanjutnya adalah mencari jumlah kehilangan panas secara konveksi dengan memasukkan rumus rumus sebagai berikut:

$$
\begin{aligned}
& Q k o n v=h A\left(T s-T_{f}\right) \\
& A=\frac{\pi}{4} D^{2} L \\
& h=\frac{n u \cdot k}{L c} \\
& R a=\frac{g \beta\left(T s-T_{f}\right) D^{3}}{v^{2}} P r \\
& L c=D \\
& g=9,8 \frac{m}{s^{2}} \\
& T_{f}=\frac{\left(T^{1}+T_{5}\right)}{2} \\
& T_{f}=\frac{(469+25)}{2} \\
& T_{f}=247^{\circ} \mathrm{C}=520^{\circ} \mathrm{K} \\
& \beta=\frac{1}{T_{f}} \\
& \beta=\frac{1}{520^{\circ} \mathrm{K}}=0,001923
\end{aligned}
$$

Berdasarkan Tabel steam properti pada suhu $520^{\circ} \mathrm{K}$ uap air memiliki:

$\mathrm{pr}=0,996 ; \mathrm{k}=0,339 ; v=38,6 \times 10^{-6} ; \mathrm{Cp}$ $=1,985$

Untuk mencari kehilangan panas karena radiasi dapat dicari dengan rumus:

$\operatorname{Qrad}=\varepsilon \cdot \sigma \cdot A\left(T_{1}^{4}-T_{2}^{4}\right)$
Dengan:

$\varepsilon=$ emissivitas ( $0 \mathrm{~s} / \mathrm{d} 0,9)$ semakin tinggi semakin baik seiring dengan kualitas lapisan pelindung panas.

$\sigma=$ Konstanta Stefan-Boltzman $\left(5,67 \times 10^{-8} \mathrm{~W} / \mathrm{m}^{2} \mathrm{~K}^{4}\right)$

$A=$ Luas area transfer panas $\frac{\pi D^{2}}{4}\left(\mathrm{~m}^{2}\right)$

$T_{1}=$ Temperatur permukaan pada inlet $\left({ }^{\circ} \mathrm{K}\right)$

$T_{2}=$ Temp. permukaan pada outlet $\left({ }^{\circ} \mathrm{K}\right)$

Untuk mendapatkan jumlah steam yang terkondensasi ( $\mathrm{ms}$ ) menggunakan persamaan:

$m s=\frac{\operatorname{Qradx} L x 3,6 x f}{h f g+\left(\operatorname{Cpx}\left(T_{2}-T_{1}\right)\right.}$

Untuk mengetahui kehilangan temperature dapat menggunakan rumus thermodinamika sehingga mendapatkan penurunan temperatur:

$m s=\frac{\operatorname{Qradx} L x 3,6 x f}{h f g+\left(\operatorname{Cpx}\left(T_{1}-T_{2}\right)\right.}$

Sehingga menjadi :

$h f g+\left(C p\left(T_{1}-T_{2}\right)=\frac{\operatorname{Qrad} x \operatorname{Lx} 3,6 \times f}{m s}\right.$

\section{METODE PENELITIAN}

\section{Tempat dan Waktu Penelitian}

Penelitian ini dilaksanakan di sepanjang jalur distribusi steam di lokasi kerja PT. Kaltim Nitrate Indonesia (KNI), untuk memudahkan proses penelitian penulis membagi wilayah obyek penelitian menjadi tiga bagian yaitu pada saluran distribusi steam (piping), pada lapisan pelindung panas, dan pada alat penjebak uap air (steam trap) waktu penelitian dimulai Bulan April sampai Bulan Mei 2017. Lokasi penelitian spt diunjukan pada gambar 2, 3, dan 4 dibawah ini: 


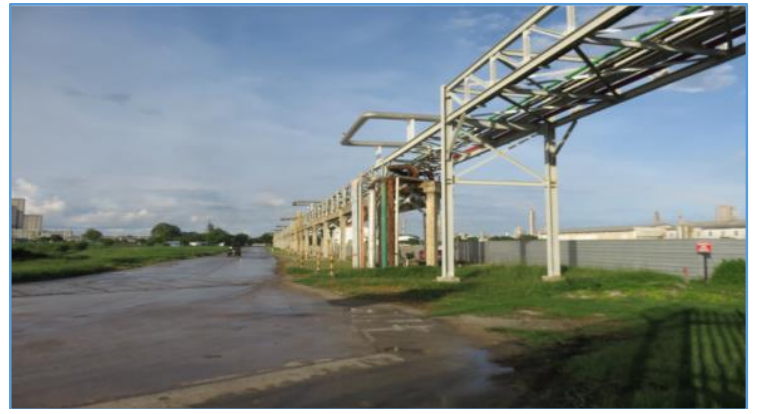

Gambar 2. Saluran Distribusi Steam

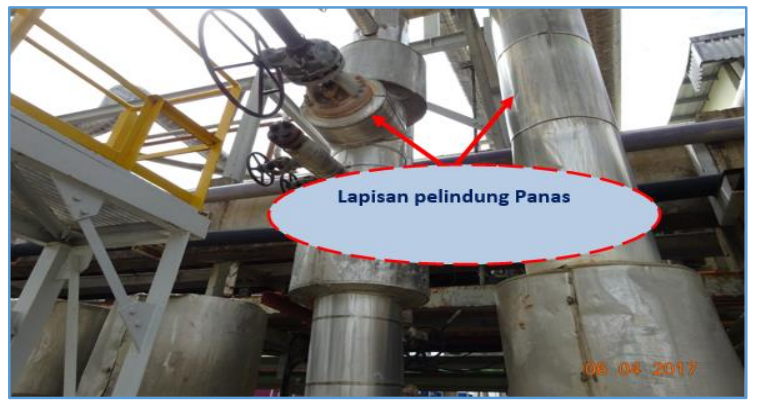

Gambar 3. Lapisan Pelindung Panas

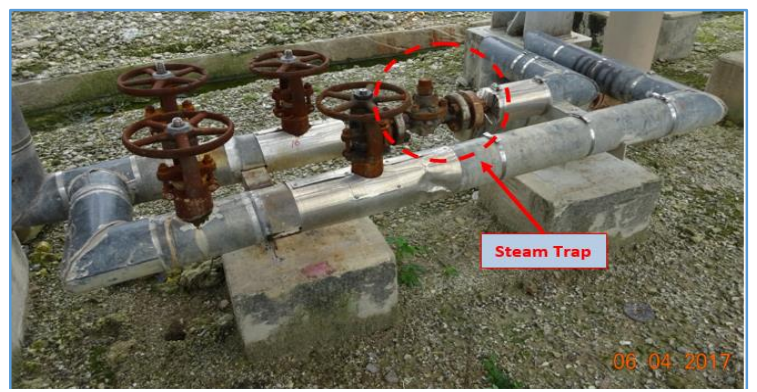

Gambar 4. Alat Penjebak Uap Air (Steam

Trap)

\section{Alat dan Bahan Penelitian}

Peralatan dan bahan yang digunakan dalam penelitian ini adalah:

1. Ultra Sonic Sound Meter

Ultra Sonic Sound Meter adalah alat untuk mendeteksi adanya aliran steam atau kondensat pada Stean Trap. Dengan alat ini kita dapat mengetahui kondisi peralatan (Steam Trap) masih sesuai dengan desain operasional atau mengalami kebocoran diatas ambang batas yang telah ditentukan sehingga penulis dapat menentukan langkah dan jenis perbaikan yang sesuai.

2. Thermo Gun

Thermo Gun merupakan alat untuk mendeteksi temperatur suatu permukaan benda dengan cara menyentuh permukaan dengan sensor yang berupa sinar laser. Alat ini berguna untuk memastikan adanya aliran atau rambatan panas pada permukaan suatu benda.

\section{Teknik Pengumpulan data}

Pengumpulan data ini menggunakan beberapa sumber sebagai acuan teoritis untuk menganalisa data. Metode teknik pengumpulan data dalam penelitian ini antara lain:

\section{Metode studi literatur}

Studi literatur pada penelitian ini, yaitu pengumpulan data teknik yang terkait dengan obyek penelitian yang ada pada dokumen kontrol PT. Kaltim Nitrate Indonesia dan mempelajari berbagai skripsi, hasil penelitian, jurnal, berbagai artikel yang diperoleh dari internet yang berhubungan dengan pemenafaatan energi steam untuk alat transfer panas maupun sebagai energi potensial untuk memutar turbin uap, makalah ilmiah dan sumber bacaan lain yang menunjang penelitian dan masalah yang akan dibahas.

2. Metode kaji lapangan

Yaitu dengan mengambil data-data penelitian secara langsung di lapangan. Langkah - langkah yang dilakukan dalam pengumpulan data penelitian di lapangan adalah:

1. Pengambilan data penelitian di lapangan

2. Mengolah data penelitian yang didapatkan dengan menggunakan rumus atau persamaan.

3. Menganalisa data penelitian yang didapatkan

4. Menarik kesimpulan dari hasil penelitian yang dilakukan.

\section{Teknik Analisa Data}

Teknik analisa data menggunakan teknik deskriptif berdasarkan hasil penelitian yang dilakukan. Data yang diperoleh dari hasil penelitian dilapangan kemudian dianalisis menggunakan rumus perpindahan panas untuk mencari kehilangan panas konduksi, konveksi, radiasi, menganalisa kondisi steam trap serta kehilangan remperatur dan 
selanjutnya menyimpulkan hasil analisa data tersebut untuk mengetahui permasalahan yang terjadi.

\section{HASIL DAN PEMBAHASAN}

Saluran distribusi steam merupakan saluran yang sangat penting bagi PT. Kaltim Nitrate Indonesia. Saluran ini menghubungkan sumber energi (steam header) yang ada di area PT. Kaltim Daya Mandiri dan Metering Station yang ada di PT. Kaltim Nitrate Indonesia, disinilah lokasi pembacaan secara otomatis jumlah steam yang diterima dalam satuan ton per jam. Selain Metering Station, header juga terpasang flow meter yang terintegrasi dengan DCS (Direct Control System) yang ada di ruang kendali PT. Kaltim Daya Mandiri. Namun pembacaannya selalu berbeda karena adanya jarak dan perpindahan panas ke lingkungan (radiasi). Berdasarkan kesepakatan, flow meter yang ada di PT. Kaltim Daya Mandiri yang digunakan sebagai dasar perhitungan jumlah penggunaan steam oleh PT. Kaltim Nitrate Indonesia. Seperti yang sudah dijelaskan sebelumnya bahwa penelitian ini meliputi tiga (3) bagian utama yaitu:

1. Saluran Distribusi Steam (Piping)

2. Lapisan Pelindung Panas (Insulation)

3. Pembuangan Steam Kondensat (Steam Trap)

Ketiga bagian inilah berdasarkan teori dan pengamatan yang memberikan kontribusi yang paling besar terhadap hilangnya steam (Steam loss) dan penurunan temperatur (Temperature Loss) pada saluran distribusi steam sepanjang 1008 meter dari PT. Kaltim Daya Mandiri menuju PT. Kaltim Nitrate Indonesia.

\section{Data Lapangan}

Berdasarkan data sheet dan obsevasi di lapangan saluran distribusi steam dari PT. Kaltim Daya Mandiri ke PT. Kaltim Nitrate Indonesia terdiri dari beberapa rangkainan antara lain:

1. Pipa

2. Elbow

3. Valve dan aksesorisnya.
Pada gambar 6 tampak sangat jelas rangkaian pipa, elbow serta valve dan aksesoris. Semua pipa dan elbow di sambung menjadi satu kesatuan sepanjang saluran distribusi steam. Proses penyambungan dilakukan dengan metode pengelasan sehingga aman dari kebocoran. Pada ujung pipa header dipasang valve yang berfungsi sebagai katup pengaman yang dapat dibuka dan ditutup sesuai kebutuhan, misalkan saat perbaikan pada saluran distribusi yang dilakukan setiap tahun sekali. Selain itu pada header juga terpasang by pass valve yang berfungsi sebagai katup untuk melakukan pemanasan (heating up) pada line pipa setelah diperbaiki, line by pass memiliki diameter yang lebih kecil dari pada saluran utama yaitu 3" sehingga steam yang melalui saluran distribusi memiliki flow yang lebih sedikit dan mudah dikontrol. Dengan adanya by pass ini pemanasan dapat dilakukan secara perlahan dan bertahap. Hal ini dilakukan agar pipa tidak rusak karena mengalami panas kejut termal shock yang berlebihan.

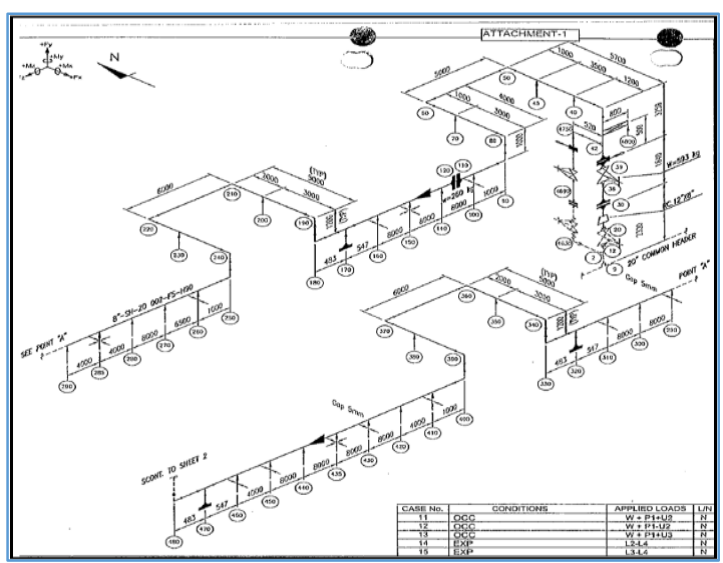

Gambar 5. P and ID Saluran Distribusi

Material pipa dan aksesorisnya terbuat dari bahan yang tahan terhadap panas yang tinggi yaitu A335-P11 menurut standart $A S M E$, atau yang sering disebut pipa baja tanpa sambungan Chrome moly (Seamless Chrome Moly Alloy Steel) karena mengandung Chromium dan Molybdenum. Dengan adanya kedua unsur tadi pipa menjadi lebih tahan pada temperatur hingga $510^{\circ} \mathrm{C}$. Selain material pemilihan ketebalan pipa juga sangat penting agar pipa mampu 
bekerja pada tekanan tertentu yang sesuai dengan operational pabrik. Setiap pipa memiliki ketebalan yang berbeda beda tergantung pada schedule (sch) yang digunakan. Dengan menggunakan pipa berdiameter 8" dan schedule 120 saluran distribusi memiliki pipa dengan ketebalan $18,2626 \mathrm{~mm}$ yang mampu menahan tekanan lebih dari $86,6 \mathrm{~kg} / \mathrm{cu} . \mathrm{cm}$ sehingga mampu mengalirkan steam dengan baik tanpa takut adanya pipa rusak karena kelebihan tekanan meskipun pipa dalam kondisi panas karena rambatan panas dari steam. Pada tabel 1 menggambarkan data teknis pipa saluran distribusi.

Tabel 1. Data Teknis Pipa Saluran Distribusi

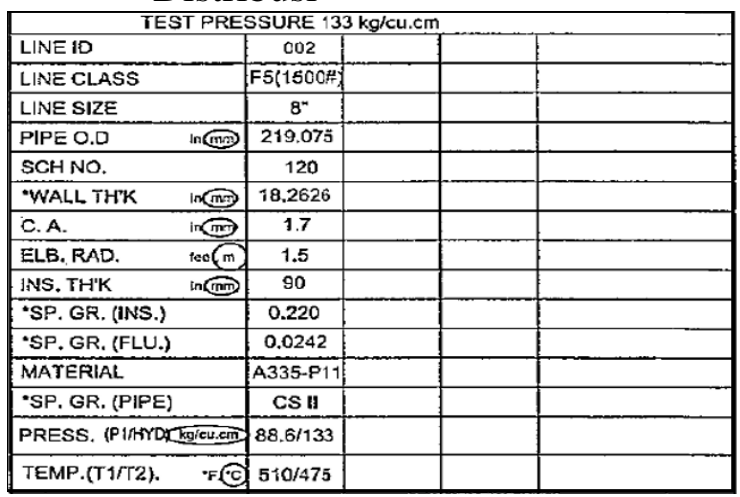

Berdasarkan data diatas, meskipun pipa di lalui oleh steam superheated dengan temperatur $470 \quad{ }^{\circ} \mathrm{C}$ dan tekanan 79 $\mathrm{kg} / \mathrm{cu} . \mathrm{cm}$ tidak terlalu berpengaruh terhadap kondisi pipa. Sebagai gambaran penulis mengambil data yang tersedia di Direct Control System PT. Kaltim Daya Mandiri untuk memastikan kondisi steam yang mengalir di saluran distribusi. Pada gambar 6 tampak parameter parameter yang berkaitaan dengan steam mulai dari tekanan yang bekerja, temperatur uap kering, jumlah pemakaian steam dalam ton per jam hingga jumlah pemakaian steam secara keseluruhan dalam ton.

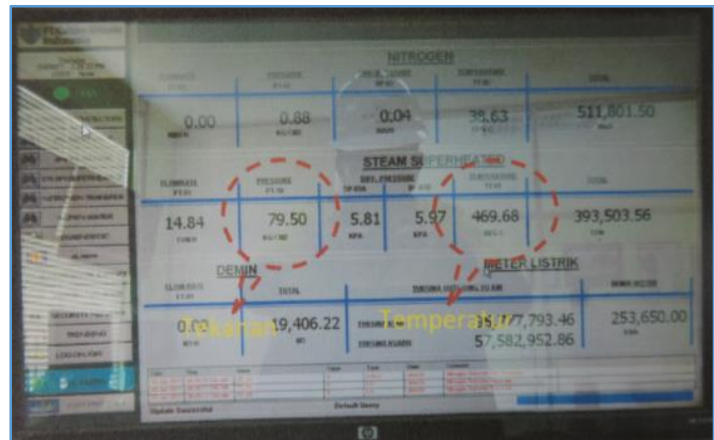

Gambar 6. Data Teknik Steam Superheated

Setelah mengetahui material pipa dan data steam properties, penulis coba mencari data yang berkaitan dengan panjang pipa. Hal ini sangat penting karena data ini digunakan sebagai acuan untuk mengetahui jumlah perpindahan panas maupun laju perpindahan panas yang terjadi pada pipa distribusi sebagai dasar pemasangan lapisan pelindung panas secara maksimal dan ekonomis untuk mengurangi laju perpindahan panas secara radiasi ke lingkungan sekitar.

\section{Steam trap}

Berdasarkan $\mathrm{P}$ and ID sepanjang saluran distribusi terpasang alat penjebak uap air atau steam trap dengan jumlah 20 unit sehingga jumlah total adalah 23 unit karena ditambah 3 unit di area Outside Battery Limit PT. Kaltim Nitrate Indonesia. Semua steam trap menggunakan type yang sama yaitu Thermodynamic/Thermostatic. Steam trap ini mampu bekerja pada temperatur $528{ }^{\circ} \mathrm{C}$ pada tekanan 88,5 $\mathrm{kg} / \mathrm{cm}^{2}$. Artinya secara desain steam trap ini aman digunakan pada saluran distribusi steam, berikut adalah tabel 2 yang memuat steam trap data sheet. 
Tabel 2. Steam Trap Data Sheet

DATA SHEET FOR STEAM TRAPS

\begin{tabular}{|c|c|c|c|}
\hline \multicolumn{2}{|l|}{ GENERAL } & & REMARKS \\
\hline \multicolumn{2}{|l|}{ TAG NO } & HST & 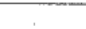 \\
\hline \multicolumn{2}{|l|}{ QUANTITY/PCS } & 20 & \\
\hline \multicolumn{2}{|l|}{ TYPE } & $\begin{array}{l}\text { THERMODYNAMICI } \\
\text { THERMOSTATIC }\end{array}$ & (Note : 2) \\
\hline \multicolumn{2}{|c|}{ LOCATION/SERVICE } & $\begin{array}{l}\text { Line Trap Header SH Existing to } \\
\text { BL }\end{array}$ & \\
\hline \multicolumn{2}{|l|}{ LINE NUMBER } & 8"-SH-ZO-002-F5-H90 & \\
\hline \multicolumn{2}{|l|}{ LINE CLASS } & F5 & \\
\hline \multicolumn{4}{|l|}{ DESIGN CONDITION } \\
\hline \multicolumn{4}{|l|}{ CAPACITY } \\
\hline $\begin{array}{l}\text { NORMAL } \\
\text { RATE }\end{array}$ & $\mathrm{Kg} / \mathrm{Hour}$ & 300 & \\
\hline \multicolumn{2}{|l|}{ SAFETY FACTOR } & & (Note : 2) \\
\hline PRESSURE & $\begin{array}{l}\mathrm{Kg} / \mathrm{Cm}^{2} \\
\mathrm{G}\end{array}$ & 88.5 & \\
\hline TEMPERATURE & $O C$ & 528 & \\
\hline \multicolumn{4}{|c|}{ OPERATING CONDITION } \\
\hline \multicolumn{2}{|l|}{ FLUID } & HP STEAM CONDENSATE & \\
\hline $\begin{array}{l}\text { OPERATING } \\
\text { PRESSURE }\end{array}$ & $\begin{array}{l}\mathrm{Kg} / \mathrm{Cm}^{2} \\
\mathrm{G}\end{array}$ & 80 & \\
\hline TEMPERATURE & ${ }^{\circ} \mathrm{C}$ & 480 & \\
\hline $\begin{array}{l}\text { BACK } \\
\text { PRESSURE }\end{array}$ & $\begin{array}{l}\mathrm{Kg} / \mathrm{Cm}^{2} \\
G\end{array}$ & 1.5 & \\
\hline $\begin{array}{l}\text { MINIMUM } \\
\text { DIFFERENTIAL } \\
\text { PRESSURE }\end{array}$ & $\begin{array}{l}\mathrm{Kg} / \mathrm{Cm}^{2} \\
\mathrm{G}\end{array}$ & 77.5 & \\
\hline
\end{tabular}

Dengan mengetahui kondisi piping, lapisan pelindung panas dan steam trap penulis dapat menghitung besarnya perpindahan panas yang yang terjadi secara keseluruhan dan besarnya kondensat yang terbuang ke kondensat port sehingga mampu menjawab permasalahan penelitian sebagai mana di bawah ini:

1. Apa sebab terjadinya kehilangan steam sepanjang saluran distribusi steam?

2. Apa sebab terjadinya penurunan temperatur steam sepanjang saluran distribusi steam?

3. Bagaimana solusi yang tepat guna melakukan perbaikan dan mengurangi kerugian karena kehilangan steam dan penurunan temperatur?

\section{Pembahasan Kehilangan Panas Konduksi dan Konveksi}

Kebutuhan steam PT. Kaltim Nitrate Indonesia diperoleh dari PT. Kaltim Daya Mandiri. Steam tersebut didistribusikan melalui saluran distribusi steam sepanjang 1008 meter pada kondisi superheated dengan tekanan awal 79 barg dan akan turun menjadi 76 barg setibanya di metering station yang ada di PT. Ka;ltim Nitrate Indonesia. Selama proses distribusi, steam akan kehilangan energi dalam bentuk panas, hal ini karena adanya perpindahan panas secara radiasi dari pipa distribusi ke lingkungan. Panas yang hilang terebut didapatkan dari entalpi penguapan dan entalpi latent yang dimiliki steam superheated. Setelah kehilangan entalpi tersebut maka steam akan berubah fasa menjadi cair atau kondensat.

Untuk mengetahui besarnya steam yang hilang penulis mencoba melakukan pendekatan rumus rumus perpindahan panas yang telah di paparkan di bab sebelumnya.

Pada gambar 7 adalah ilustrasi pipa dan lapisan pelindung panas sebagai gambaran untuk memudahkan penulis dalam menyajikan perhitungan tentang hilangnya steam pada saluran distribusi.

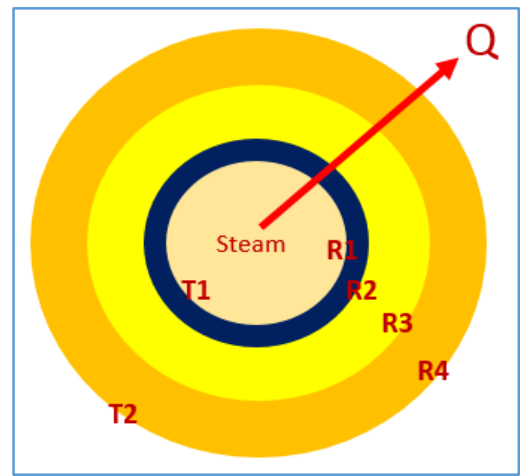

Gambar 7. Ilustrasi Pipa dan Lapisan Pelindung Panas.

Berdasarkan gambar diatas penulis coba mencari besarnya perpindahan panas secara konduksi dengan memasukkan data data yang telah ada.

$\mathrm{D} 1=182 \mathrm{~mm}=0,182 \mathrm{~m}$

$\mathrm{D} 2=219 \mathrm{~mm}=0,219 \mathrm{~m}$

D3 $=269 \mathrm{~mm}=0,269 \mathrm{~m}$

D4 $=309 \mathrm{~mm}=0,309 \mathrm{~m}$

D5 $=313 \mathrm{~mm}=0,313 \mathrm{~m}$

$\mathrm{k} 1=$ Kond. Termal pipa $=50 \mathrm{kkal} / \mathrm{m} \cdot \mathrm{jam}^{\circ} \mathrm{C}$

$\mathrm{k} 2=$ Kond. Termal isolasi $=0,075$ $\mathrm{kkal} / \mathrm{m} . \mathrm{jam}^{\circ} \mathrm{C}$

$\mathrm{k} 3=$ Kond. Termal isolasi $=0,075$ $\mathrm{kkal} / \mathrm{m} . \mathrm{jam}^{\circ} \mathrm{C}$ 
$\mathrm{k} 4=$ kond. Termal Aluminium $=150$

$\mathrm{kkal} / \mathrm{m}$.jam ${ }^{\circ} \mathrm{C}$

$T_{1}=469^{\circ} \mathrm{C}, T_{5}=25^{\circ} \mathrm{C}$

Laju perpindahan kalor per satuan panjang adalah qL

Qkond $=\frac{2 \pi L\left(T_{1}-T_{5}\right)}{\sum_{i=1}^{n} \frac{1}{k_{1}} \ln \frac{d n_{1}}{d_{1}}}$
$\frac{\text { Qkond }}{L}=\frac{2 \pi\left(T_{1}-T_{5}\right)}{\sum_{i=1}^{n} \frac{1}{k_{1}} \ln \frac{d n_{1}}{d_{1}}}$
$\frac{\text { Qkond }}{L}=\frac{2 \pi\left(T_{1}-T_{5}\right)}{\frac{1}{k_{1}} \ln \frac{d_{2}}{d_{1}}+\frac{1}{k_{2}} \ln \frac{d_{3}}{d_{2}}+\frac{1}{k_{3}} \ln \frac{d_{4}}{d_{3}}+\frac{1}{k_{4}} \ln \frac{d_{5}}{d_{4}}}$

$\frac{\text { Qkond }}{L}$

$=\frac{2 \cdot 3,14(469-25)}{\frac{1}{50} \ln \frac{0,219}{0,182}+\frac{1}{0,075} \ln \frac{0,269}{0,219}+\frac{1}{0,075} \ln \frac{0,309}{0,269}+\frac{1}{150} \ln \frac{0,313}{0,309}}$

$\frac{\text { Qkond }}{L}=\frac{2788,320}{4,594}$

$\frac{Q k o n d}{L}=606,94 \mathrm{kkal} / \mathrm{m}$.jam

Jadi laju perpindahan panas konduksi yang terjadi sepanjang jalur distribusi sebesar 606,94k kal/m.jam. Untuk mengetahui temperatur permukaan pipa $\left(T_{2}\right)$ dapat kita cari dengan rumus sebagai berikut:

$T_{2}=T_{1}-\frac{\frac{Q k o n d}{L}}{2 \pi} \times \frac{1}{k_{1}} \ln \frac{d_{2}}{d_{1}}$

$T_{2}$

$=T_{1}$

$-\frac{606,94 \mathrm{kal} / \mathrm{m} . \mathrm{jam}}{2 \cdot 3.14} \times \frac{1}{50 \mathrm{kkal} / \mathrm{m} . \mathrm{jam}} \ln \frac{0,219}{0,182}$

$T_{2}=469-\frac{606,94}{6,28} \times 0,02 \times 0,19$

$T_{2}=469-0,367$

$T_{2}=468,6$

$T_{3}=T_{2}-\frac{\frac{Q k o n d}{L}}{2 \pi} \times \frac{1}{k_{2}} \ln \frac{d_{3}}{d_{2}}$

$=468,6^{\circ} \mathrm{C}$

$-\frac{606,94 \mathrm{kkal} / \mathrm{m} . \mathrm{jam}}{6,28} \times \frac{1}{0,075 \mathrm{kkal} / \mathrm{m} . \mathrm{jam}} \ln \frac{0,269 \mathrm{~m}}{0.219 \mathrm{~m}}$

$=468,6^{\circ} \mathrm{C}-96,65 \times 13,33 \times 0,206$ $=468,6^{\circ} \mathrm{C}-265$

$=203,6^{\circ} \mathrm{C}$

$T_{4}=T_{3}-\frac{\frac{Q k o n d}{L}}{2 \pi} \times \frac{1}{k_{3}} \ln \frac{d_{4}}{d_{3}}$

$T_{4}$

$=203,6^{\circ} \mathrm{C}-\frac{606,94 \mathrm{kkal} / \mathrm{m} . \mathrm{jam}}{2 \cdot 3.14} \times \frac{1}{0,075} \ln \frac{0,309}{0,269}$

$T_{4}=203,6^{\circ} \mathrm{C}-96,65 \times 13,33 \times 0,139$

$T_{4}=25^{\circ} \mathrm{C}$

$T_{5}=T_{4}-\frac{\frac{Q k o n d}{L}}{2 \pi} \times \frac{1}{k_{4}} \ln \frac{d_{5}}{d_{4}}$

$T_{5}=25^{\circ} \mathrm{C}-\frac{606,94 \mathrm{kkal} / \mathrm{m} . \mathrm{jam}}{2 \cdot 3.14} \times \frac{1}{150} \ln \frac{0,313}{0,309}$

$T_{5}=25^{\circ} \mathrm{C}-96,65 \times 0,007 \times 0,013$

$T_{5}=25^{\circ} \mathrm{C}-0,0087$

$T_{5}=25^{\circ} \mathrm{C}$

Setelah semua temperatur permukaan pipa dan isolasi saluran distribusi steam diketahui selanjutnya adalah mencari jumlah kehilangan panas secara konveksi dengan memasukkan rumus rumus sebagai berikut:

$Q k o n v=h A\left(T s-T_{f}\right)$

$A=\frac{\pi}{4} D^{2} L$

$h=\frac{n u \cdot k}{L c}$

$R a=\frac{g \beta\left(T s-T_{f}\right) D^{3}}{v^{2}} \operatorname{Pr}$

$L c=D$

$g=9,8 \frac{\mathrm{m}}{\mathrm{s}^{2}}$

$T_{f}=\frac{\left(T^{1}+T_{5}\right)}{2}$

$T_{f}=\frac{(469+25)}{2}$

$T_{f}=247^{\circ} \mathrm{C}=520^{\circ} \mathrm{K}$

$\beta=\frac{1}{T_{f}}$

$\beta=\frac{1}{520^{\circ} \mathrm{K}}=0,001923$ 
Berdasarkan Tabel steam properti pada suhu $520^{\circ} \mathrm{K}$ uap air memiliki:

$\mathrm{pr}=0,996 ; \mathrm{k}=0,339 ; v=38,6 \times 10^{-6} ; \mathrm{Cp}$ $=1,985$

Sehingga :

$R a=\frac{9,8 \cdot 0,001923 \cdot(469-247) 182^{3}}{\left(38,6 \times 10^{-6}\right)^{2}} 0,996$

$R a=1,7 \times 10^{7}$

$n u=\frac{h \cdot k}{L c}=\left\{0,6+\frac{0,387 R a^{1 / 6}}{\left[1+\left\{\frac{0,559}{P r}\right\}^{\frac{9}{16}}\right]^{8 / 27}}\right\}^{2}$

$n u=\frac{h \cdot k}{L c}=\left\{0,6+\frac{0,387\left(1,7 \times 10^{7}\right)^{1 / 6}}{\left[1+\left\{\frac{0,559}{0,996}\right\}^{\frac{9}{16}}\right]^{8 / 27}}\right\}^{2}$

$n u=\frac{h \cdot k}{L c}=3,66$

$h=\frac{n u \cdot k}{L c}$

$h=\frac{36,6 x \cdot 0.339}{0,182}$

$h=68 \mathrm{~W} / \mathrm{m}^{2} \cdot{ }^{\circ} \mathrm{C}$

Jadi

Qkonv $=h A\left(T s-T_{f}\right)$

Qkonv $=68 \mathrm{~W} / \mathrm{m}^{2} \cdot{ }^{\circ} \mathrm{C} \frac{3,14}{4} 0,182^{2} \cdot(469-247)$

Qkonv $=392,5 \mathrm{~W} / \mathrm{m}^{2} \cdot{ }^{\circ} \mathrm{C}$

\section{Pembahasan Kehilangan Panas Radiasi}

Steam yang telah kehilangan panas akan berubah menjadi kondensat, hal ini merupakan suatu proses yang alami dan tidak dapat dihindari. Hilang nya panas ini dipengaruhi oleh faktor lingkungan selama proses distribusi steam dari PT. Kaltim Daya Mandiri ke PT. Kaltim Nitrate Indonesia. Pada kondisi hujan kehilangan panas semakin besar dan berlaku sebaliknya. Selain itu kecepatan angin juga memiliki peranan yang sangat penting dalam proses terjadinya tranfer panas ke lingkungan.
Gambar 8 dibawah ini penulis sajikan sebagai ilustrasi saluran distribusi steam untuk memudahkan proses perhitungan laju kehilangan panas secara radiasi dengan cara memasukan parameter atau data data pada saat penelitian kedalam rumus perpindahan panas secara radiasi $(\mathrm{Q}$ rad) berdasarkan Hukum Planck.

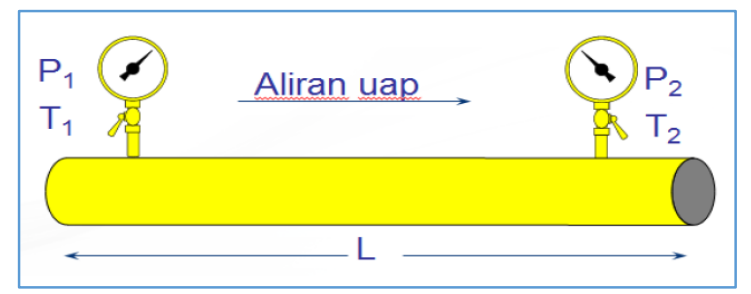

Gambar 8. Ilustrasi Saluran Distribusi steam

Tabel 3. Data Hasil Pengukuran Tekanan dan Temperatur

\begin{tabular}{|c|c|c|}
\hline No & Variabel & Nilai \\
\hline 1 & P1 & $79 \mathrm{~kg} / \mathrm{Cm}^{2}$ \\
\hline 2 & T1 & $469^{\circ} \mathrm{C} / 742^{\circ} \mathrm{K}$ \\
\hline 3 & P2 & $76 \mathrm{~kg} / \mathrm{Cm}^{2}$ \\
\hline 4 & T2 & $386^{\circ} \mathrm{C} / 659^{\circ} \mathrm{K}$ \\
\hline 5 & $\mathrm{~L}$ & $1008 \mathrm{~m}$ \\
\hline 6 & D & $182 \mathrm{~mm} / 0,182 \mathrm{~m}$ \\
\hline
\end{tabular}

Kehilangan panas karena radiasi dapat dicari dengan rumus:

Qrad $=\varepsilon \cdot \sigma \cdot A\left(T_{1}^{4}-T_{2}^{4}\right)$

Dengan:

$\varepsilon=$ emissivitas $(0 \mathrm{~s} / \mathrm{d} 0,9)$ semakin tinggi semakin baik seiring dengan kualitas lapisan pelindung panas.

$\sigma=$ Konstanta Stefan-Boltzman $\left(5,67 \times 10^{-8} \mathrm{~W} / \mathrm{m}^{2} \mathrm{~K}^{4}\right)$

$A=$ Luas area transfer panas $\frac{\pi D^{2}}{4}\left(\mathrm{~m}^{2}\right)$

$T_{1}=$ Temperatur permukaan pada inlet $\left({ }^{\circ} \mathrm{K}\right)$

$T_{2}=$ Temperatur permukaan pada outlet $\left({ }^{\circ} \mathrm{K}\right)$

Sehingga :

Qrad $=0,9 \cdot 5,67 \times 10^{-8} \mathrm{~W} / \mathrm{m}^{2} \mathrm{~K}^{4}$

$$
\frac{3,14(0,182)^{2}}{4}\left(742^{4}-289^{4}\right)
$$

Qrad $=0,9 \cdot 5,67 \times 10^{-8} \mathrm{~W} / \mathrm{m}^{2} \mathrm{~K}^{4} \cdot 0,026 \cdot 2,96 \times 10^{11}$

Qrad $=3929,546 \mathrm{~W} / \mathrm{m}$

Jadi jumlah panas yang hilang adalah $392,9546 \mathrm{~W} / \mathrm{m}$. Dari hasil perhitungan 
tersebut didapatkan jumlah steam yang terkondensasi $(m s)$.

$$
\begin{aligned}
& m s=\frac{\operatorname{Qrad} L \mathrm{Lx} 3,6 \times f}{h f g+\left(\operatorname{Cpx}\left(T_{2}-T_{1}\right)\right.} \\
& m s=\frac{3929,546 \mathrm{~W} / m \times 1008 \times 3,6 \times 0,1}{1460 \frac{\mathrm{kj}}{\mathrm{kg}}+(2,7 \times(469-386)} \\
& m s=\frac{3929,546 \mathrm{~W} / \mathrm{m} \times 1008 \times 3,6 \times 0,1}{1460 \frac{\mathrm{kj}}{\mathrm{kg}}+(2,7 \times(469-386)} \\
& m s=\frac{1425954}{1678,7} \\
& m s=849,4392 \mathrm{~kg} / \mathrm{jam}
\end{aligned}
$$

Jadi total steam yang terkondensasi sepanjang 1008 meter karena kehilangan panas secara radiasi selama proses distribusi berlangsung sebesar 0,849 ton per jam, hal ini sangat wajar mengingat sepanjang saluran distribusi steam dilapisi oleh lapisan pelindung panas yang berfungsi secara optimal. Namun perhitungan diatas tidak memasukan kecepatan angin sebagai faktor koreksi, jika kecepatan angin terukur adalah $4 \mathrm{~m} / \mathrm{s}$, maka kondensasi steam akan meningkat menjadi 1 ton per jam.

\section{Pembahasan Kondisi Steam Trap.}

Dari hasil kalkulasi steam di saluran distribusi terdapat selisih yang sangat signifikan yaitu 3,5 ton per jam. Untuk mencari hilangnya steam tersebut ada satu lagi peralatan yang berkaitan dengan hilangnya steam dan temperatur di saluran distribusi steam yaitu steam trap. Untuk mengetahui kondisi steam trap, PT. Kaltim Nitrate Indonesia mengadakan steam audit atau survey untuk memastikan kondisi steam trap beroperasi secara optimal dengan begitu tidak ada lagi steam yang terbuang kelingkungan. Pengambilan data temperatur inlet dan outlet saat steam trap survey, pengambilan data dilakukan dengan menggunakan alat Thermo Gun Flux 62 Max untuk temperatur dan Ultra Sonic Steam Trap Tester UP2000 dengan methode standart iso7841:1988.

Sepanjang jalur distribusi terdapat 23 unit steam trap yang terdiri dari 20 unit berada di area Pipe Rack yang dimulai dari header yang berada di PT. Kaltim Daya Mandiri hingga batas luar pagar PT. Kaltim Nitrate Indonesia dan 3 unit berada di batteray limit Metering Station KNI. Berdasarkan hasil survey yang dilakukan terhadap 23 unit steam trap terdapat beberapa steam trap yangberoperasi dengan baik, fail closed dan fail open. Untuk lebih jelasnya hasil survey penulis susun dalam Tabel dan grafik di bawah ini.

Tabel 4. Rangkuman Kondisi Steam Trap

\begin{tabular}{|c|c|c|c|c|c|c|c|c|}
\hline Zone & $\begin{array}{c}\text { Failed } \\
\text { Opened }\end{array}$ & $\begin{array}{c}\text { Failed } \\
\text { Closed }\end{array}$ & $\begin{array}{c}\text { Not In } \\
\text { Use }\end{array}$ & Ok & Cold & $\begin{array}{c}\text { Rapid } \\
\text { Cycle }\end{array}$ & $\begin{array}{c}\text { Not } \\
\text { tested }\end{array}$ & Total \\
\hline Total Area & 12 & 2 & 0 & 9 & 0 & 0 & 0 & 23 \\
\hline Total & 12 & 2 & 0 & 9 & 0 & 0 & 0 & 23 \\
\hline Percentage (\%) & $52.2 \%$ & $8.7 \%$ & $0 \%$ & $39.1 \%$ & $0 \%$ & $0 \%$ & $0 \%$ & $100 \%$ \\
\hline
\end{tabular}

Dari Tabel 4 diatas kondisi 23 steam trap adalah sebagai berikut:

1. $39,1 \%$ atau 9 unit dalam kondisi baik

2. $8,7 \%$ atau 2 unit berada pada kondisi fail to open, kemungkinan disebabkan adanya blocking sehingga terjadi akumulasi kondensat yang menyebabkan ssteam trap tidak bekerja. Perlu dianalisalebih lanjut untuk mengetahui penyebab pastinya.

3. $52,2 \%$ atau 12 unit berada dalam kondisi fail to close (leaking). Pada kondisi ini steam trap harus segera di ganti atau diperbaiki untuk mencegah semakin besarnya kondensat yang keluar sehingga semakin besar pula biaya yang harus dikeluarkan. Penyebab kebocoran pada steam trap yang sering terjadi adalah adanya erosi atau pengikisan pada permukaan seat dan disc, selain itu kebocoran steam trap dapat pula disebabkan adanya kesalahan dalam pemasangan atau terbalik. 


\section{Steam Trap Condition}

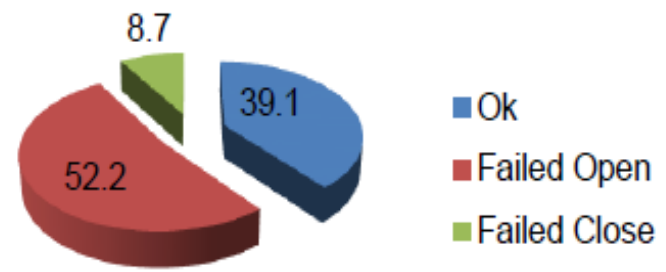

Gambar 9. grafik detail kondisi steam trap

Tabel 5. Steam Loss

\begin{tabular}{|l|l|r|}
\hline No Steam Trap & Lokasi & Steam Loss \\
\hline SP O01 & KDM & 101.29 \\
\hline SP O02 & PKT & 101.29 \\
\hline SP 005 & PKT & 101.29 \\
\hline SP 011 & PKT & 101.29 \\
\hline SP 014 & KIE & 101.29 \\
\hline SP 015 & KIE & 101.29 \\
\hline SP 016 & KIE & 101.29 \\
\hline SP 017 & KIE & 101.29 \\
\hline SP 019 & KNI & 97.13 \\
\hline SP 020 & KNI & 8.09 \\
\hline SP 021 & KNI & 8.09 \\
\hline SP O23 & KNI & 8.09 \\
\hline \multicolumn{2}{|c|}{ Jumlah Steam loss } & 931.72 \\
\hline
\end{tabular}

Berdasarkan hasil survey steam trap dapat penulis simpulkan bahwa 52,2\% steam trap dalam kondisi bocor (leaking) dan potensi kehilangan steam $932 \mathrm{~kg} / \mathrm{jam}$ atau kurang lebih satu ton per jam sebagai mana di ditunjukkan dalam grafik 4.3. jika harga setiap ton steam adalah 20 USD, maka dalam satu hari kehilangan steam senilai 480 USD atau 6.240.000 rupiah, seperti pada tabel berikut ini.

Tabel 6. Harga Steam yang terbuang

\begin{tabular}{|c|c|c|c|}
\hline Harga/USD & Hari/USD & Bulan/USD & Tahun/USD \\
\hline 20 & 480 & 14400 & 172800 \\
\hline
\end{tabular}

Kerugian bervariasi dari waktu ke waktu sebanding dengan biaya steam. Semakin banyak steam trap yang leak atau mengalami kebocoran semakin besar pula biaya yang dikeluarkan sementara nilai perbaikan steam trap tetap. Ukuran steam trap juga sangat berpengaruh terhadap nilai steam loss, semakin besar oriface semakin banyak pula steam yang terbuang sia sia pada steam trap yang bocor. Kebocoran pada steam trap berakibat meningkatnya biaya kebutuhan energi, meningkatkan emisi carbon, menimbulkan potensi bahaya baru bagi pekerja dan menurunkan margin keuntungan serta kehandalan operasional pabrik. Dengan berbagai alasan di atas maka sangat disarankan untuk mengganti stean trap yang rusak atau memperbaiki steam trap yang bermasalah.

\section{Pembahasan Kehilangan Temperatur}

Berdasarkan kalkulasi hasil survey dapat penulis simpulkan bahwa sepanjang saluran distribusi telah terjadi kehilangan steam yang disebabkan oleh dua (2) faktor utama yaitu:

1. Laju perpindahan panas secara simultan pada saluran distribusi sebesar satu setengah $(1,5)$ ton per jam

2. Kondisi steam trap yang bermasalah (Leaking) sebesar satu (1) ton per jam.

Jadi jumlah total kehilangan steam sebesar dua koma lima $(2,5)$ ton per jam, jika jumlah itu dimasukkan kedalam rumus thermodinamika akan mendapatkan penurunan temperatur yang penulis cari.

$$
\begin{aligned}
& m s=\frac{Q \operatorname{Qrad} x \operatorname{Lx} 3,6 \times f}{h f g+\left(\operatorname{Cpx}\left(T_{1}-T_{2}\right)\right.} \\
& h f g+\left(C p\left(T_{1}-T_{2}\right)=\frac{Q \operatorname{rad} \times L \times 3,6 x f}{m s}\right. \\
& \left(469-T_{2}\right)=\frac{3929,546 \mathrm{~W} / m \times 3,6 \times 0,1}{\frac{2470}{2,7}}-1460 \\
& \left(469-T_{2}\right)=95,58 \sim 96^{\circ} \mathrm{C} \\
& \left(T_{2}\right)=469-96^{\circ} \mathrm{C} \\
& \left(T_{2}\right)=373^{\circ} \mathrm{C}
\end{aligned}
$$

Jadi setelah melewati saluran distribusi sepanjang 1008 meter steam mengalami penurunan temperatur sebesar $96^{\circ} \mathrm{C}$. Hal ini disebabkan steam mengalami kondensasi dan berubah menjadi air seiring dengan penurunan temperatur. Proses ini merupakan hal yang normal terjadi dalam steam karena proses pembentukannya.

\section{KESIMPULAN}

1. Kehilangan steam diakibatkan oleh dua faktor utama yaitu: 
a. Laju perpindahan secara simultan yang terjadi pada jalur distribusi.

b. Kondisi steam trap yang bocor (leaking)

2. Penurunan temperatur secara signifikan terjadi karena perubaham fase.

3. Perlu pengecekan dan perbaikan berkala sehingga setiap kerusakan yang terjadi dapat diketahui secara dini.

\section{DAFTAR PUSTAKA}

[1]. Muntolib \& Rusdiyantoro (2014). Analisa Bahan Isolasi Pipa Saluran Uap Panas Pada Boiler Untuk Meminimalisasi Heat Loss. Jurnal Teknik WAKTU Volume 12 Nomor 02 - Juli 2014 - ISSN : 14121867.

[2]. Anonim, (2016) Steam Trap Audit PT. Kaltim Nitrate Indonesia Bontang

[3]. Cengel, Y. A. (2002). Heat Tasfer a Partical Approach with EES $C D$, New York : McGraw-Hill Science Engineering.

[4]. Holman, J. P. (1997). Perpindahan Kalor, Jakarta : Penerbit Airlangga.

[5]. Haryanto, Agus (2015). Perpindahan Panas, Yogyakarta : Penerbit Innosain. 